\title{
Biochemical studies on hepatic involvement in infectious mononucleosis
}

\author{
D. N. BARON, JOYCE L. BELL, AND W. N. DUNNET ${ }^{1}$ \\ From the Departments of Chemical Pathology and Infectious Diseases, \\ Royal Free Hospital, London
}

SYNOPSIS Eighty cases of infectious mononucleosis have been investigated by serum enzyme studies and other liver function tests.

Maximum abnormalities occurred between the second and fourth weeks of illness and all tests were usually normal by the sixth week. Serum isocitric dehydrogenase activity was increased in $93 \%$ of cases and serum glutamic-oxaloacetic transaminase in $74 \%$. Conventional liver function tests were less sensitive. Serum bilirubin was above normal in $40 \%$ of cases; in $17 \%$ of cases the increase was sufficient to show as clinical jaundice.

No patient has developed chronic hepatitis.

The incidence of jaundice and of liver damage in infectious mononucleosis is undecided. Leibowitz (1953), reviewing 3,000 published cases from 1923-51, found 144 cases of jaundice, with an incidence in individual reports of $1.4 \%$ to $25 \%$. With the advent of enzyme tests as sensitive indicators of hepatocellular damage (Baron, 1963) it was considered timely to re-examine the problem.

\section{MATERIAL}

Eighty consecutive unselected cases of infectious mononucleosis admitted to the infectious diseases department of the Royal Free Hospital between August 1959 and November 1962 have been studied. The clinical, haematological, and immunological findings and criteria for diagnosis have been described in detail elsewhere (Dunnet, 1963). Blood was taken for biochemical examination approximately twice weekly while the patient was in hospital (in certain instances more frequently), and at less frequent intervals after discharge until repeated tests were normal. Some patients were visitors and students from abroad, consequently routine follow-up examination after discharge in every case was impracticable. This paper is confined in the main to an investigation of the acute phase of the disease.

\section{METHODS}

During the period of this survey the following methods, with modifications, were employed for analysis of serum.

${ }^{1}$ Present address: Epidemiological Section, Ministry of Health, London.

Received for publication 25 June 1964.
Glutamic-oxaloacetic transaminase (G.O.T.) (Reitman and Frankel, 1957); isocitric dehydrogenase (I.C.D.) (Bell and Baron, 1960); total and differential proteins (Wolfson, Cohn, Calvary, and Ichiba, 1948); total and conjugated bilirubin (Malloy and Evelyn, 1937); alkaline phosphatase (King and Armstrong, 1934); thymol turbidity, thymol flocculation, and colloidal gold flocculation (Maclagan, 1944); zinc sulphate turbidity (Kunkel, 1947). This work was done before the introduction of the new terminology and international units for enzymes.

\section{RESULTS}

Maximum abnormality of all biochemical findings occurred between the second and fourth weeks of illness, this period being about a week later than that of maximum clinical involvement. By the sixth week these abnormalities had usually returned to normal, except that the serum I.C.D. was often raised for a further week.

Enzyme tests were abnormal in a higher proportion of cases than were conventional 'liver function tests'. Isocitric dehydrogenase was elevated in 74 cases $(93 \%)$ and G.O.T. in 58 cases $(74 \%)$. Of conventional liver function tests, the most sensitive tests appeared to be thymol turbidity, abnormal in 42 out of 68 cases tested $(62 \%)$, though thymol flocculation was only abnormal in $41 \%$; alkaline phosphatase, abnormal in 37 out of 67 cases tested $(55 \%)$ and above 30 units in nine cases $(13 \%)$; and colloidal gold, abnormal in 28 out of 54 cases tested $(52 \%)$. Zinc sulphate turbidity was abnormal in only 16 out of 66 cases tested $(24 \%)$. Serum 
globulin rose above normal in 29 out of 63 cases tested $(46 \%)$; serum albumin was below normal in only four cases $(6 \%)$ with no correlation with other evidence of severe disease. Serum total bilirubin was raised in 26 out of 69 cases tested (40\%). Thirteen patients $(17 \%)$ were clinically jaundiced whilst there was clinical evidence of hepatic involvement (tenderness or hepatomegaly) in 29 patients $(36 \%)$.

Serum G.O.T. or I.C.D. values did not reflect the severity of infection as judged by pyrexia and general clinical findings, nor was there any correlation with heterophil antibody titre or degree of lymphocytosis (Dunnet, 1963). High G.O.T. or I.C.D. values were not necessarily associated with hyperbilirubinaemia, whereas all patients with a serum alkaline phosphatase above $35 \mathrm{~K}$-A units had a raised serum bilirubin level.

Figure 1 shows a correlation of biochemical and clinical findings in a typical case. Although the patient did not complain of sore throat and no

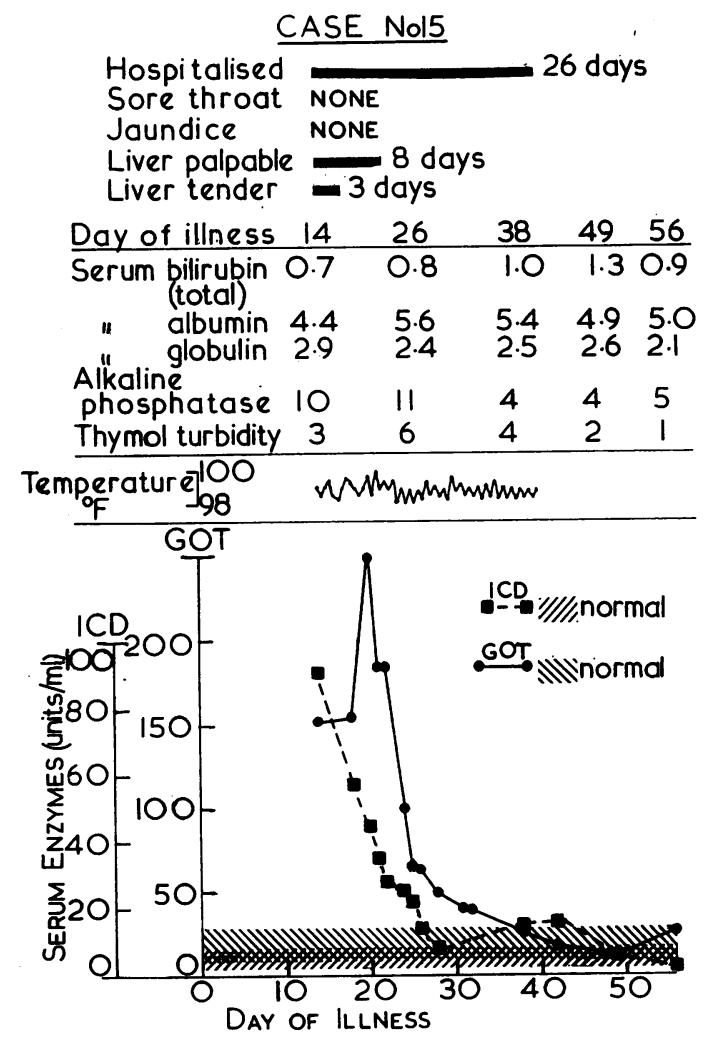

FIG. 1. Correlation between serum enzyme values and other biochemical and clinical findings in a typical case of infectious mononucleosis. exudate was present there was plum-coloured injection of the fauces. There was hepatomegaly and hepatic tenderness for a few days after admission but there was no jaundice and at that time the only abnormal biochemical findings were of the thymol turbidity and colloidal gold tests. It will be noted that the serum bilirubin rose to $1.3 \mathrm{mg} . / 100 \mathrm{ml}$. on the fiftieth day of the disease but there was no clinical evidence of jaundice. There were no abnormal findings in the urine.

\section{DISCUSSION}

Frequent hepatic involvement in infectious mononucleosis has been shown by liver biopsy (Nelson and Darragh, 1956; Sullivan, Irey, Pileggi, Crone, and Gibson, 1957), conventional liver function tests (Wechsler, Rosenblum, and Sills, 1946; Schultz and Hall, 1952; Mason and Adams, 1958), and serum transaminases (Sullivan et al., 1957; Rosalki, Jones, and Verney, 1960) and other enzymes (Kalk, Schmidt, Schmidt, and Wildhirt, 1960).

We consider that the abnormal enzyme findings in infectious mononucleosis are due to almost universal hepatocellular damage; neither serum I.C.D. nor serum G.O.T. are increased in generalized lymph gland disease without known hepatic involvement. In the present series serum I.C.D. was found to be the most sensitive index. In none of the patients with normal serum I.C.D. was there other evidence of hepatitis (Dunnet, 1963). We have no evidence as to the frequency of liver involvement in mild cases of the disease treated at home.

In the series of Berk, Shay, Ritter, and Siplet (1948), with a similar incidence of jaundice, there was a higher proportion of abnormal flocculation reactions and increased serum alkaline phosphatase. Sullivan et al. (1957) showed a lower incidence of jaundice, but a higher incidence of abnormal zinc sulphate tests and raised serum globulin. Gelb, West, and Zimmerman (1962) found a higher incidence of raised serum globulin (but equivalent abnormal flocculations) and of serum alkaline phosphatase, and less increase of serum isocitric dehydrogenase. The high serum lactic dehydrogenase found by them and by Kalk et al. (1960) is thought to originate in the affected lymphatic system. The differences between these series can be largely explained on different relative severities of illness, and possibly on methodological criteria.

The poor correlation between elevated enzyme values, and clinical jaundice or immunological findings, is in keeping with the observations of Wadsworth and Keil (1952) and of Rosalki et al. (1960). Previous studies have suggested that hepatitis has subsided by the fifth week of the disease, by 
evidence from liver biopsy (Nelson and Darragh, 1956) and by serum transaminase estimations (Rosalki et al., 1960). In this series many patients showed biochemical abnormalities into the sixth week and by the most sensitive test of liver cell damage (serum I.C.D.) into the seventh week. Very careful history taking in this series has often elicited vague complaints of malaise and general weariness which may precede even by a week the acute symptoms such as sore throat and fever by which the patients usually tend to date the beginning of their illness.

It has been suggested that hepatitis in infectious mononucleosis may become chronic (Bennett, Frankel, Bedinger, and Baker, 1950) or lead to cirrhosis (Leibowitz and Brody, 1950). In the present series in one case serum I.C.D. was minimally raised and colloidal gold still abnormal seven months after the onset of the illness, after which time contact with the patient was lost. In three years since the beginning of this study no cases of chronic hepatitis were observed in the 40 patients who were followed.

Much of the material in this article was included in the thesis by W.N.D. accepted for the degree of M.D. (Aberdeen). We wish to thank Dr. W. Gunn and Dr.
A. M. Ramsay for access to patients under their care and for much advice, and Dr. Roger Williams for valuable criticism.

\section{REFERENCES}

Baron, D. N. (1963). Proc. roy. Soc. Med., 56, 173.

Bell, J. L., and Baron, D. N. (1960). Clin. chim. Acta, 5, 740.

Bennett, H. D., Frankel, J. J., Bedinger, P., and Baker, L. A. (1950). Arch. intern. Med., 86, 391.

Berk, J. E., Shay, H., Ritter, J. A., and Siplet, H. (1948). Gastroenterology, 11, 658 .

Dunnet, W. N. (1963). Brit. med. J., 1, 1187.

Gelb, D., West, M., and Zimmerman, H. J. (1962). Amer. J. Med., 33, 249.

Kalk, H., Schmidt, E., Schmidt, F. W., and Wildhirt, E. (1960). Klin. Wschr., 38, 421.

King, E. J., and Armstrong, A. R. (1934). Canad. med. Ass. J., 31, 376. Kunkel, H. G. (1947). Proc. Soc. exp. Biol. (N. Y.), 66, 217.

Leibowitz, S. (1953). Infectious Mononucleosis. Grune and Stratton, New York.

—, and Brody, H. (1950). Amer. J. Med., 8, 675.

Maclagan, N. F. (1944). Brit. J. exp. Path., 25, 234.

Malloy, H. T., and Evelyn, K. A. (1937). J. biol. Chem., 119, 481.

Mason, W. R. Jr., and Adams, E. K. (1958). Amer. J. med. Sci., 236, 447.

Nelson, R. S., and Darragh, J. H. (1956). Amer. J. Med., 21, 26.

Reitman, S., and Frankel, S. (1957). Amer. J. clin. Path., 28, 56.

Rosalki, S. B., Jones, T. G., and Verney, A. F. (1960). Brit. med. J., 1, 929.

Schultz, A. L., and Hall, W. H. (1952). Ann. intern. Med., 36, 1498.

Sullivan, B. H. Jr., Irey, N. S., Pileggi, V. J., Crone, R. I., and Gibson, J. R. (1957). Amer. J. dig. Dis., 2, 210.

Wadsworth, R. C., and Keil, P. G. (1952). Amer. J. Path., 28, 1003.

Wechsler, H. F., Rosenblum, A. H., and Sills, C. T. (1946). Ann. intern. Med., 25, 113.

Wolfson, W. Q., Cohn, C., Calvary, E., and Ichiba, F. (1948). Amer. J. clin. Path., 18, 723. 